\title{
ANTARA MORAL EKONOMI DAN EKONOMI RASIONAL PADA POLA PROGRAM DENFARM S.R.I (Studi pada P3A Padibu Kecamatan Ulakan Tapakis dan P3A Banda Iduik Kecamatan Nan Sabaris)
}

\author{
Panji Asrywan ${ }^{1 *}$, Damsar ${ }^{2}$, Bob Alfiandi ${ }^{3}$ \\ ${ }^{1}$ Graduate Student of Department of Sociology, Universitas Andalas, Padang, Indonesia \\ ${ }^{2}$ Department of Sociology, Universitas Andalas, Padang, Indonesia \\ ${ }^{3}$ Department of Sociology, Universitas Andalas, Padang, Indonesia
}

\section{ARTICLE INFORMATION}

Submitted : 18 August 2018

Review : 05 April 2019

Accepted : 11 May 2019

Available online: June 2019

\section{KEYWORDS}

Moral Economy, Farmer's Rationale, Denfarm Pattern S.R.I, P3A

\section{CORRESPONDENCE}

^E-mail: panjiasrywan718@gmail.com

\section{A. PENDAHULUAN}

$\mathrm{S}$ alah satu masalah utama Indonesia yang belum terpecahkan hingga saat ini adalah rawannya ketersediaan pangan. Pasca swasembada pangan tahun 1983, Indonesia telah menjadi salah satu Negara pengimpor beras di dunia (Kasryno, et.al, 2001). Data impor beras lima tahun ke belakang, secara dinamis, menunjukkan Indonesia masih mengimpor beras. Seperti data tahun 2013, menunjukkan jumlah impor beras Indonesia mencapai 1.225 .000 ton. Jumlah impor kemudian meningkat pada tahun 2014 sebanyak 1.350 .000 ton. Sejak tahun 2015 sampai 2017, jumlah impor mengalami penu runan dari 1.000 .000 sampai 500.000 ton saja (IRRI 2018).

\section{A B S T R A C T}

This study aims to see the syncretism between the moral and rational economics of farmers on the Denfarm program pattern S.R.I in P3A Padibu and P3A Banda Iduik Ulakan Tapakis and Nan Sabaris Subdistricts. They also understand the relation of economic and moral rational syncretism of farmers to the Denfarm Pattern of S.R.I. The Denfarm program of S.R.I pattern is carried out by the government so that farmers can increase rice production. This activity was carried out on P3A Padibu and P3A Banda Iduik Ulakan Tapkis Subdistrict and Nan Sabaris Sub-District, but the results obtained were very different. There is a sociological problem affecting the Denfarm production pattern of S.R.I. The data analysis used is qualitative hermeneutical analysis using moral economic theory James Scoot and Rational Farmer Samuel Popkin. The result of the research shows that the low production of Denfarm pattern of S.R.I P3A Padibu is caused by the chairman who commits lying and stealing in order to reach the personal interest. Besides, the chairman has no sense of responsibility towards Denfarm activity which gives impact to the appearance of the lazy nature of other participants. Perta also has another more productive land so that participants ignore the results obtained from the land of the Denfarm program. The high production of Denfarm P3A Banda lduik occurs because it has a rational thought but nature is formed because it wants to depends the good name of P3A group, therefore, they are afraid to fail in this activity.

Sebenarnya kesenjangan produksi ini sudah lama disadari oleh pemerintah Indonesia. Pembangun sektor pertanian di Indonesia, pernah mengadaptasi pembangunan pertanian padi. Satari (2002) mencatat, setidaknya sejak 1993/1994 pemerintah telah mencoba mene rapkan bimbingan masyarakat (bimas), dengan menekankan pada produksi beras dan hasilnya dapat meningkatkan produksi beras selama setahun. Salah satu alat yang diadopsi oleh pemerintah Indonesia untuk peningkatan produksi dibidang pertanian dengan metode "Demontration of Farming" (Denfarm) menggunakan teknik "System of Rice Intensification" (S.R.I).

Dalam rangka meningkatkan hasil pertanian, pada tahun 2014 Pemerintah 
mencoba menerapkan kembali penanaman padi menggunakan pola S.R.I melalui program Denfarm yang merupakan salah satu bentuk penerapan teknologi pertanian dalam upaya peningkatan produksi hasil pertanian. Pemerintah telah melakukan kegiatan tersebut dari tahun 2015, akan tetapi hanya mampu memproduksi padi dengan rata-rata 5 ton per hektar sehingga Indonesia masih mengimpor beras dari Negara lain. Upaya lain yang dilakukan Pemerintah untuk memacu petani dalam meningkatkan hasil produksi, dengan cara melibatkan Pemerintah Kabupaten/Kota sampai dengan Perintahan terendah yang berada di Kecamatan kedalam kegiatan Denfarm pola S.R.I. karena dapat menjangkau setiap lapisan petani, salah satu program Denfarm pola S.R.I yang cukup berhasil dilakukan di daerah Sukoharjo Jawa Tengah Kementerian Pertanian mencatat hasil produksi padi mencapai 10,4 ton per hektar. Selain itu, Denfarm pola S.R.I yang dilakukan di Desa Karangkatas Kabupaten Indramayu Jawa Barat memproduksi jumlah padi sebanyak 12 ton/hektar sampai 14,5 ton/hektar.

Bercermin dari keberhasilan tersebut, pemerintah juga mencanangkan di Pulau Sumatera tepatnya di Kecamatan Ulakan Tapakis dan Kecamatan Nan Sabaris Kabupaten Padang Pariaman Provinsi Sumatera Barat. Pada teknis pelaksanaan terpilih dua kelompok Perkumpulan Petani Pemakai Air (P3A), pertama P3A Padibu kedua P3A Banda Iduik. Akan tetapi metode Denfarm pola S.R.I yang diterapkan di P3A Padibu tidak menunjukkan hasil yang maksimal hanya 4,2 ton/ha sangat berbeda dengan P3A Banda Iduik yang telah mencapai swasembada dengan jumlah 10,9 ton/ha. Artikel ini bertujuan untuk melihat secara perspektif sosiologis-antropologis apa yang menyebabkan perbedaan hasil program diatas.

\section{B. METODE PENELITIAN}

$\mathrm{P}$ enelitian ini dilakukan selama 5 bulan (dari September 2017 sampai Maret 2018) di Nagari Sei Gimba Ulakan, Kecamatan Ulakan Tapakis, dan Nagari Pauh Kamba, Kecamatan Nan Sabaris, Kabupaten Padang Pariaman, Provinsi Sumatra Barat. Metode yang digunakan adalah kualitatif hermeneutik, karena metode ini memiliki beberapa kelebihan. Pertama, penelitian kualitatif hermeneutik berguna untuk memahami secara lebih mendalam tentang makna (arti subjektif dan penafsiran) dan konteks tingkah laku serta proses yang terjadi pada faktor-faktor yang berkaitan dengan tingkah laku tersebut. Kedua, metode penelitian kualitatif hermeneutik berguna untuk mengungkapkan proses kejadian secara mendetail, sehingga diketahui dinamika sebuah realitas sosial dan saling pengaruh antar realitas sosial. Ketiga, metode penelitian kualitatif berguna untuk mengetahui realitas sosial dari sudut pandang aktor.

\section{HASIL DAN PEMBAHASAN 1. P3A Padibu}

$\mathrm{P}$ 3A Padibu adalah salah satu organisasi petani yang berada pada daerah Irigasi Batang Anai fase II, berdiri pada tanggal 27 Juni 2014 P3A Padibu memiliki pintu air di sekunder BPT 4 dengan petak tersier BPT $4 \mathrm{Ka}$ dan Ki serta memilik luas wilayah kerja 128 ha, rata-rata petani P3A Padibu merupakan petani penggarap hanya beberapa orang petani yang memliki lahan sendiri atau pemilik. Sedangkan P3A ini terletak di Korong Sikabu, Nagari Sei Gimba, Kecamatan Ulakan Tapakis, Kabupaten Padang Pariaman.

P3A ini dibentuk oleh beberapa gabungan Instansi pemerintah seperti Dinas PSDA Provinsi Sumatera Barat, Dinas PU Kabupaten Padang Pariaman, Dinas Pertanian Kabupaten Padang Pariaman, Kodim Padang Pariaman, Balai Wilayah Sungai Sumatera $V$ dan Konsultan Pemberdayaan serta di hadiri oleh pemerintah tingkat Nagari setempat. Instansi Pemerintah ini berperan menjelaskan seperti apa fungsi dan peran $\mathrm{P} 3 \mathrm{~A}$, dalam pembangunan pertanian serta apa tupoksi dari pengurus serta anggota dalam tubuh P3A sendiri.

Setalah semua persyaratan dipenuhi oleh P3A Padibu, pada tanggal 27 Agustus 2017 dilakukan penanaman pertama Denfarm pola S.R.I P3A Padibu. Di dalam proses pelaksanaan semua kegiatan dilakukan dengan standar prosedur dinas pertanian sehingga dari segi penanaman dan pemeliharaan semua sama dengan standarrisasi yang telah diatur oleh pemelintah. Dalam penelitian ini terdapat beberapa fakta yang menjadi penyebab kegagalan Denfarm pola S.R.I P3A Padibu antara lain:

\section{a. Kehidupan Mewah}

Fakta-fakta yang peneliti temukan dilapangan menunjukkan gaya hidup petani P3A Padibu yang cukup mewah, mereka memiliki rumah yang cukup bagus, serta memiliki setiap anggota keluarga memiliki masing-masing sepeda motor untuk alat transportasi. Walaupun mereka hanya sebagai penggarap atau buruh tani yang mengolah sawah dan membagi hasil dengan pemilik lahan akan tetapi mereka 
memiliki penghasilan tambahan dalam memenuhi kebutuhaan keluarga, bukan dengan beternak atau menanam tanaman yang memiliki nilai jual, akan tetapi sebagai tukang bangunan dan berjualan barang kebutuhan sehari-hari.

Selain itu mereka tidak fokus hanya pada satu lahan pertaniaan saja, akan tetapi juga menggarap beberapa lahan yang lebih berada di tempat yang berbeda. Sehingga mereka tidak menghiraukan apabila terdapat kerugian atau penurunan hasil panen di lahan yang dijadikan tempat praktek Denfarm, karena rata-rata lahan mereka yang dipakai untuk program Denfarm hanya 1 sampai dengan 0,5/ha.

\section{b. Kecurangan Ketua P3A Padibu}

Kegagalan lain yang terjadi dalam program Denfarm P3A Padibu adalah kecurangan yang dilakukan oleh ketua P3A, dengan cara menimbun pupuk yang akan dibagikan kepada peserta lainnya, hal ini terjadi karena ketua P3A ingin mencari keuntungan dari penimbunan pupuk, yang akan digunakan untuk modal kampanye menjadi Wali Nagari, praktek-praktek kebohongan ini sesuai dengan teori Scott yakni lima senjata orang yang kalah, seperti pada saat pelaksanaan program ketua lebih memilih untuk berdiam diri dan tidak melaksanakan semua aturan yang dilakukan oleh tim pelaksana, Ketua bersama perserta lainnya lebih suka mengiyakan, setelah sosialisasi selesai mereka pun tidak mengaplikasikan teori yang mereka dapat.

\section{c. Perserta Tidak Memiliki Rasa Tanggung Jawab}

Pada saat pelaksaan program Denfarm pola S.R.I peserta P3A Padibu tidak terfokus pada satu lahan saja, terdapat beberapa lahan garapan yang di lokasi yang berbeda, sehingga jarak dan waktu peserta terbagi. Selain itu pupuk yang diperuntukkan untuk kegiatan Denfarm tidak digunakan sesuai dengan takaran Dinas Pertanian, persoalan tersebut menyebabkan tidak produktif-nya lahan Denfarm P3A Padibu.

Peserta P3A Padibu tidak hanya melakoni pekerjaan sebagai petani, tetapi mereka memiliki pekerjaan lainnya untuk memenuhi kebutuhan rumah tangga, peserta Denfarm yang bertani ini, memiliki kehidupan yang cukup layak, semua peserta memiliki pekerjaan lain seperti bekerja sebagai kuli bangunan, memiliki warung kopi, beternak lele bahkan ada yang memiliki heller (tempat pengolahan padi). Oleh karena itu mereka memiliki asumsi, kurang pun hasil panen yang di dapatkan, mereka akan tetap makan dan masih dapat memenuhi kebutuhan lainnya.

\section{d. Pendidikan}

Peserta P3A Padibu rata-rata tidak memliki pendidikan tinggi, persoalan tersebut terjadi karena pada masa sekolah mereka telah diperkenalkan dengan uang sehingga dengan sendirinya timbul rasa malas dari diri mereka, para orang tua di Nagari Ulakan dahulu lebih suka menyuruh anaknya untuk berkerja, dari pada untuk bersekolah yang hanya akan menghabiskan uang, sehingga timbul dalam pikiran mereka untuk menghasilkan uang yang lebih banyak. Hanya tiga orang dari tujuh peserta Denfarm P3A Padibu yang menamatkan sekolah tingkat SMA. Dua orang lainnya hanya menyelesaikan pendidikan sampai tingkat SD, bahkan dua orang lagi tidak pernah menempuh pendidikan sama sekali. Sehingga faktor pendidikan juga menjadi salah satu kegagalan Denfarm P3A Padibu, mereka lebih memilih cara bertani dengan teknik konvensional, karena menurut mereka dengan sistem yang berbeda lebih banyak memakan waktu dan tenaga, sehingga mereka hanya terfokus pada lahan Denfarm. Selain itu dalam kegiatan ini para peserta tidak mau untuk digurui, atau diajarkan cara bertani mengunakan teknik S.R.I dan menyebabkan kegagalan dalam kegiatan ini.

\section{Keberhasilan P3A Banda Iduik}

P3A Banda Iduik merupakan P3A yang mendapatkan hasil panen terbaik di program Denfarm pola S.R.I pada tahun 2017, yang mengalahkan P3A Padibu dengan total panen 10,9 ton/ha. Pencapaian ini melebihi target, yang hanya 8 sampai 9 ton/ha. Hasil ini merupakan hasil Denfarm tertinggi sejak program ini dilaksanakan di daerah irigasi Batang Anai mulai dari tahun 2014 sampai 2017.

P3A Banda Iduik lolos pada tahap pemilihan awal karena memenuhi persyaratan yang ditentukan, diantaranya merupakan P3A yang mandiri dan memiliki beberapa prestasi di tingkat 
Kecamatan, Kabupaten dan Provinsi. Bahkan P3A Banda Iduik juga pernah menjuarai lomba P3A tingkat Kabupaten Padang Pariaman. Serta memiliki saluran irigasi yang cukup terawat dan antusias masyarakat Pauh Kamba Hilir yang sangat tinggi.

Keberhasilan P3A Banda Iduik dalam program Denfarm pola S.R.I, terjadi karena masyarakat terbuka terhadap sesuatu yang baru, akan tetapi keterbukaan tersebut memiliki alasan untuk mempertahankan nama baik kelompok mereka di mata Pemerintah Daerah dan Pemerintah Kecamatan serta di masyarakat luas. Program Denfarm pola S.R.I merupakan teknologi pertanian yang baru masuk ke daerah Pauh Kamba Hilia, biasanya masyarakat melakukan bercocok tanam dengan cara lama atau konvensional. Peserta P3A Banda Iduik merupakan petani yang bisa dikatakan cukup menerima sesuatu hal yang baru, dan menjalan setiap aturan yang di berlakukan demi keberhasilan kegiatan ini.

Setiap dalam pelaksaan program yang dilakukan wali nagari yang juga merangkap sebagai ketua P3A selalu memberikan motivasi. Akan tetapi didalam tersebut juga terdapat pengambilan keuntungan yang dilakukan oleh perserta P3A Banda Iduik, akan tetapi hal tersebut tidak merugikan Pemerintah.

\section{Diskusi}

Petani Denfarm P3A Padibu, sangat berbeda dengan pandangan James Scott bahwa petani orang yang memiliki hidup digaris subsistensi yang apabila salah dalam mengambil tindakan maka kehidupan mereka akan jadi pertaruhan, sehingga mereka mengutamakan konsep dahulukan selamat atau "Safety Frist". Akan tetapi yang peneliti temukan dari lapangan, tidak memperlihatkan bahwa perserta Denfarm P3A Padibu tidak sama dengan pengertian petani menurut James Scott dan para ahli ilmuan sosial lainnya. Karena kehidupan mereka masih sangat jauh dari pandangan Scott tersebut. Moral ekonomi petani didasarkan atas norma subsistensi dan norma resiprositas dimana tindakan seorang petani apabila menghadapi suatu keadaan yang dapat merugikan kelangsungan hidup mereka, maka mereka akan menjual dan menggadai harta mereka (Scott, 1982: 399- 411).

Wolf dalam bukunya yang berjudul petani suatu tinjauan antropologis menyebutkan bahwa peasan pada umumnya bersifat subsistensi, mereka tidak begitu memikirkan profit dari hasil pertaniannya, akan tetapi mereka lebih memikirkan bagaimana cara bertahan hidup dan menjamin kebutuhan dalam keluarga mereka. Menurut Wolf, mereka jauh lebih maju dari pada petani yang cultivator, hal tersebut disebabkan karena mereka sudah mengenal sistem sewa tanah, dan sudah memakai teknik-teknik pertanian maju seperti sistem hidrolik atau sistem irigasi dalam memudahkan pengairan areal persawahan mereka Wolf (1966: 22). Dengan kata lain petani menurut Wolf petani maju memiliki pemikiran modern, serta sudah memiliki cikal bakal jiwa kapitalis.

Redfield menjelaskan bahwa suatu masyarakat yang mengolah tanah mereka sendiri sebagai suatu cara memepertahankan hidup secara tradisional akan tetapi sangat kental dengan penagaruh kaum elit desa yang memiliki cara hidup yang lebih beradab (Redfield 1982:20). Dalam masyarakat petani tersebut menurut Redfield, mereka memiliki kesamaan dalam bertindak dan berpikir untuk hidup yang lebih baik serta memiliki memiliki solidaritas yang tinggi dalam kelompok tersebut akan tetapi petani sebagai produsen, menganut pandangan hidup yang tinggi terhadap tanah yang mereka kuasai sendiri, sehingga mereka selalu berhubungan dengan wilayah kota, atau kota besar. Redfield menegaskan petani sebagai suatu dimensi sivilisasi kedesaan namun mereka hidup dalam hubungan pasar-pasar dikota dalam meningkatkan taraf ekonomi dan dalam memenuhi kebutuhan hidup (Redfield, 1982:9093).

Terilham dari pemikiran Theodore W. Shcultz salah seorang ekonom neo-klasik, Popkin menjelaskan petani sangat responsif terhadap kekuatan pasar yang bergerak setiap saat. Hal itu terlihat dalam pemanfaatan peluang oleh petani dan dalam pengambilan keputusan yang rasional dalam mengalokasikan hasil pertanian mereka, perlawanan mereka terhadap pihak penguasa jangan diartikan secara sempit. Teori moral ekonomi menurut Scott, akan terjadi apabila dalam kondisi mendesak sehingga mereka akan mendahulukan diri, dan keluarga mereka (Popkin, 1986:78). Menurut Chayanov dalam Peasant Society tidak ada mengenal kata tenaga kerja di dalam kehidupannya, karena ekonominya terdiri dari satuan-satuan "usaha tani keluarga" atau UK yang melainkan tidak 
memiliki upah serta dikerjakan oleh semua anggota keluarga secara bersama-sama, UK tersebut tidak memiliki sifat profit maximization. (Chayanov dan Wiradi 1993: 13-14).

Menurut Popkin dalam (Damsar dan Indrayani, 2016: 243-246) petani desa tidak bisa dilihat dari kaca mata ekonomi rasional, karena petani tersebut makhluk yang rasional dengan mempertimbangkan segala sesuatunya dan berbagai macam alternatif yang ada yang dapat meningkatkan kehidupan dan kesejahteraan hidupnya. Sehingga petani melakukan investasi baik dalam jangka panjang maupun dalam waktu jangka pendek dengan demikian mereka melakukan investasi yang berisiko baik dan investasi yang aman. Peserta P3A Padibu dan P3A Banda Iduik, mereka memiliki akal yang rasional dalam bertindak untuk memenuhi kebutuhan sehari-hari mereka, dan mereka melakukan itu dengan menggunakan lima senjata orang yang kalah, untuk mencapai tujuan dari mereka.

\section{Tabel 1. Temuan Hasil Penelitian}

\begin{tabular}{|c|c|c|c|}
\hline No. & James Scott & Samuel Popkin & Temuan Hasil Penelitian \\
\hline 1 & Etika Subsistensi & Petani Rasional & $\begin{array}{l}\text { Petani denfarm memiliki kemauan untuk meningkatkan } \\
\text { kualitas hidup serta berpedoman kepada filsafat minang, } \\
\text { yang ditanamkan secara turun temurun. Serta tidak hanya } \\
\text { terfokus kepada satu pekerjaan saja suami atau istri memiliki } \\
\text { mata pencarian ganda. }\end{array}$ \\
\hline 2 & Safety First & $\begin{array}{l}\text { Petani memiliki } \\
\text { Investasi Jangka } \\
\text { panjang dan jangka } \\
\text { pendek }\end{array}$ & $\begin{array}{l}\text { Petani denfarm memiliki investasi jangka panjang dan } \\
\text { jangka pendek, akan tetapi untuk mencapai tujuan tersebut } \\
\text { mereka menggunakan lima senjata orang yang kalah (teori } \\
\text { Scott) }\end{array}$ \\
\hline 3 & $\begin{array}{l}\text { Norma } \\
\text { Resiprositas }\end{array}$ & Hubungan Eksploitatif & $\begin{array}{l}\text { Petani Denfarm memiliki hubungan yang baik dengan } \\
\text { pemilik lahan, sehingga tidak hanya satu lahan saja digarap } \\
\text { oleh petani Denfarm terdapat lahan lain yang digarap } \\
\text { dengan pemilik yang berbeda-beda. }\end{array}$ \\
\hline 4 & $\begin{array}{l}\text { Perlawanan } \\
\text { Petani }\end{array}$ & $\begin{array}{ll}\text { Perlawanan } & \text { Petani } \\
\text { dipandang } & \text { sebagi } \\
\text { suatu masa } & \text { depan } \\
\text { yang lebih baik } & \end{array}$ & $\begin{array}{l}\text { Petani Denfarm menuju hal yang lebih baik dengan } \\
\text { menggunakan senjata orang yang kalah (teori scott) }\end{array}$ \\
\hline
\end{tabular}

Fakta-fakta yang peneliti temukan di lapangan menunjukkan gaya hidup petani yang cukup mewah, mereka memiliki rumah yang cukup bagus, serta memiliki setiap anggota keluarga memiliki masing-masing sepeda motor untuk alat transportasi. Walaupun mereka hanya sebagai penggarap atau buruh tani yang mengolah sawah dan membagi hasil dengan pemilik lahan akan tetapi mereka memiliki pengahasilan tambah dalam memenuhi kebutuhaan keluarga, bukan dengan bertenak atau menanam tanaman yang memiliki nilai jual, akan tetapi sebagai tukang bangunan dan berjualan barang kebutuhan sehari-hari.

Mereka tidak fokus hanya pada satu lahan pertanian saja, akan tetapi juga menggarap beberapa lahan yang lebih berada di tempat yang berbeda. Sehingga mereka tidak menghiraukan apabila terdapat kerugian atau penurunan hasil panen di lahan yang dijadikan tempat praktek Denfarm, karena rata-rata lahan mereka yang dipakai untuk program Denfarm hanya 1 sampai dengan 0,5/ha.

Kegagalan lain yang terjadi dalam program Denfarm P3A Padibu adalah kecurangan yang dilakukan oleh ketua P3A, dengan cara menimbun pupuk yang akan dibagikan kepada peserta lainnya, hal ini terjadi karena ketua P3A ingin mencari keuntungan dari penimbunan pupuk, yang akan digunakan untuk modal kampanye menjadi Wali Nagari, praktek-praktek kebohongan ini sesuai dengan teori Scott lima senjata orang yang kalah, seperti pada saat pelaksaan program ketua lebih memilih untuk berdiam diri dan tidak melaksanakan semua aturan yang dilakukan oleh tim pelaksana, Ketua bersama perserta lainnya lebih suka mengiyakan, setelah sosialisasi selesai mereka pun tidak mengaplikasikan teori yang mereka dapat.

Menurut Skocpol (1991: 41) untuk melakukan perlawan petani harus memiliki pengaruh internal, pengaruh tersebut terjadi 
karena petani saling memiliki rasa kebersamaan dan senasib sehingga menimbulkan rasa kekompakan dalam diri mereka sehingga dengan seperti itu perlawanan tersebut akan muncul, peneliti sendiri juga memiliki padangan berbeda, peneliti memilihat bahwa dalam kehidupan peserta P3A Padibu memiliki sifat saling menjatuhkan dan ingin menang sendiri atau seperti "sabik" (mengambil keuntungan sendiri). Mereka tidak memiliki sifat yang homogen, akan tetapi siapa yang pintar dan cerdik akan menindas yang lemah, walaupun mereka masih memiliki hubungan saudara satu dengan yang lainnya, yang cerdik tersebut hanya ingin mencapai tujuannya saja tanpa mempertimbangkan efek dari perbuatannya tersebut. Terdapat sedikit kemiripan dengan pendapat Boeke (1973: 37) petani lebih cenderung mendahulukan kebutuhan dalam diri mereka sendiri, dan tidak ikut serta dalam kegiatan yang sifatnya yang mendahulukan kepentingan bersama.

Keberhasilan P3A Banda Iduik dalam program Denfarm pola S.R.I, terjadi karena masyarakat terbuka terhadap sesuatu yang baru, akan tetapi keterbukaan tersebut memiliki alasan untuk mempertahankan nama baik kelompok mereka di mata Pemerintah Daerah dan Pemerintah Kecamatan serta di masyarakat luas. Setiap dalam pelaksaan program yang dilakukan wali nagari yang juga merangkap sebagai ketua P3A selalu memberikan motivasi. Akan tetapi di dalam tersebut juga terdapat pengambilan keuntungan yang dilakukan oleh peserta P3A Banda Iduik, akan tetapi hal tersebut tidak merugikan Pemerintah.

\section{KESIMPULAN}

$\mathrm{B}$ erdasarkan temuan diatas peneliti menyarankan kepada pihak yang terkait dengan program Denfarm pola S.R.I agar lebih memilih dengan standar yang berlaku untuk pelaksaan program Denfarm berikutnya, serta merubah cara pendekatan kepada masyarakat harus mempertimbangkan kajian sosial budaya pada daerah tersebut, karena setiap aturan dan sistim pendekatan terhadap masyarkat yang menggunakan program Denfarm merupakan adopsi dari pulau Jawa, sehingga karakteristik petani yang berbeda berdampak kepada tujuan yang tidak tepat sasaran. Oleh karena itu penelitian ini menjadi masukan untuk pihak-pihak yang terkait dengan pelaksanaan Denfarm pola S.R.I.

\section{E. UCAPAN TERIMAKASIH}

U capan terimakasih saya sampaikan kepada Balai Wilayah Sungai Sumatera V, Pemerintah Kabupaten Padang Pariaman khusunya Dinas Pekerjaan Umum bidang Irigasi dan rawa, Dinas pertanian Kabupaten Padang Pariaman, Kodim 0308 Pariaman khususnya Danramil Nan Sabaris, Camat Ulakan Tapakis, Camat Nan Sabaris, Kapolsek Pauh Kamba, Wali Nagari Sei Gimba, Wali Nagari Pauh Kamba, serta instansi yang mendukung penelitian ini.

\section{DAFTAR PUSTAKA}

Damsar dan Indriani. (2009). Pengantar Sosiologi Ekonomi. Kencana

Marzali, Amri. (2003). Strategi Peisan Cikalong Dalam Menghadapi Kemiskinan. Yayasan Obor Indonesia. Jakarta

Scott, James. (1993). Perlawanan Kaum Tani. Terjemahan. Yayasan Obor Indonesia. Jakarta

Kasryno, Faisal dan Stepanek, Joseph. (1985). Dinamika Pembangunan Pedesaan. Gramedia. Jakarta

Popkin, Samuel. (1986). Petani Rasional.Yayasan Padamu Negeri. Jakarta

Redfield, Robert. (1982). Masyarakat Petani dan Kebudayaan. Terjemahan CV. Raja Wali. Jakarta. Indonesia

Shanin, Teodor (ed). (1971). Peasant and Peasant Societies. Penguin Books. Australia

Shanin, Teodor (ed). (1971). On Peasant Rebellion, Middlesex: Penguin Books.

Skocpol, Theda. (1991). Negara dan Revolusi Sosial : Suatu Analisis Komparatif Tentang Perancis, Rusia, dan Cina. Jakarta :Erlangga 